\title{
Role Satisfaction and Social Support of Mothers in Entrepreneurial Role in India
}

\author{
Aarthi P Arulmurugan and Jayasree Lakshmi
}

\begin{abstract}
This study aimed at exploring the role satisfaction and social support of mothers in entrepreneurial role. In this study, the researcher studied the role satisfaction and social support of mothers in entrepreneurial role and also the strategies they used to balance between the roles to create a better environment for their family and overall community. The study involved 5 mothers who were in entrepreneurial role. The study employed a qualitative research design. The sample was chosen using purposive sampling technique. Formal interviews were conducted to explore role satisfaction and social support. The responses were analyzed using Thematic analysis. The study found that the mothers who are entrepreneurs were satisfied with their roles and received social support. They used strategies such us effective time management techniques, pre planning and taking care of one self in order to maintain a balance between both the roles. The study helped the researcher to identify the issues they face in balancing the roles and the strategies used.
\end{abstract}

Keywords-Role Satisfaction, Social Support, Women Entrepreneur.

\section{INTRODUCTION}

Educated women do not want to limit their lives in the four walls of the house. They demand equal respect from their partner and society. However, in Indian context women requires a large effort to achieve equal rights and position because traditions are deep rooted in Indian society where the sociological set up has been a male dominated one(Teo,1996). Women are considered as weaker sex and always made to depend on men folk in their family and outside, throughout their life (Allen and Trumen,1993). The Indian culture made them only subordinates and executors of the decisions made by other male members, in the basic family structure. While at least half the brainpower on earth belongs to women, women remain perhaps the world 's most underutilized resource. Despite all the social hurdles, India is brimming with the success stories of women. They stand tall from the rest of the crowd and are applauded for their achievements in their respective field. The transformation of social fabric of the Indian society, in terms of increased educational status of women and varied aspirations for better living, necessitated a change in the life style of Indian women. She has competed with man and successfully stood up with him in every walk of life and business is no exception for this. These women leaders are assertive, persuasive and willing to take risks. They

Aarthi P.A, Jain University, India

Dr.Lakshmi J, Assistant professor, Jain University, India managed to survive and succeed in this cut throat competition with their hard work, diligence and perseverance. Ability to learn quickly from her abilities, her persuasiveness, open style of problem solving, willingness to take risks and chances, ability to motivate people, knowing how to win and lose gracefully are the strengths of the Indian women entrepreneurs.[1]

Motherhood completes a women-hood is what most of the women believe. The motherly feeling cannot be explained but can only be experienced. The warmth, security, unconditional love we get from our mother is matchless. When did they become so selfless? Are they really happy and satisfied with what they are? Don't they have any expectations? Being a mother as well as an entrepreneur is challenging in life. It requires immense effort and patience. With multiple responsibilities on their plates, mothers are often the CEOs of their families. Delegation is one of the most important survival skills for working moms and startup founders alike. While a young single founder might still be able to scrape by without a team by simply putting in crazy work hours, mom entrepreneurs need to learn how to delegate much earlier. Delegating the grocery list to a family member might be more similar to delegating the design of a logo to a freelancer than most people would think.[2]

Their managerial skills are inimitable. This paper helped the researcher understand the technique any women should possess to balance in work and family life.

A study found that Indian woman entrepreneurs faced lower levels of work-family conflicts and seem to differ in their reasons for starting and succeeding in business (Das,2012). Another study suggested that the social and economic problems faced by women entrepreneurs were male domination, unwritten rules of society and family responsibilities, lack of economic power, no right over property, dependence on male members on banking and such others (Rao, 2002).A study on Self-efficacy in work and parental roles proved to be a significant predictor of women's work-family conflict and role overload, respectively. In addition, satisfaction with their child care was related to significantly less anxiety about being separated from their young children (Erdwins, Buffardi, Casper \& O'brien, 2011). A study suggested that a strong identification with their family roles, in particular the role as a mother, lead Japanese women onto the entrepreneurial path. A strong gender role identity is also reflected in the identity of the ventures, the products and services provided by these ventures, and their organizational structure and practices [2]. According to another research 
finding, the strategy of resignation was more frequently used by single mothers with lower work satisfaction, who were distinctly different from those whose work satisfaction was higher, and from the mothers in relationships (Nepora,,Andruszkiewicz \& Baniska,2018)

\section{METHODOLOGY}

The study attempted to understand role satisfaction and social support of mothers in entrepreneurial role, issues they faced by them and strategies used by them in balancing the roles. Immense amount of research has gone into understanding the current variables and this chapter deals with the nature of the study, its objectives as well as describing the procedure along with the tools used for the current study in full. The aim of the study is to explore the role satisfaction and social support of mothers in entrepreneurial role. The objectives of the study are to explore the role satisfaction of mothers in entrepreneurial role, to explore the challenges faced by individual as mothers and entrepreneur, to explore how women entrepreneurs, manage job roles and motherhood roles simultaneously and to understand the social support of them. The study used a Qualitative research design which explores to understand the role satisfaction and social support in mothers in entrepreneurial role. Purposive sampling technique was used as the sampling method. The samples were mothers who were in entrepreneurial venture and the sample size were 5. Entrepreneurs who have at least one child with the age group of 3-9 years. Entrepreneurs who had a minimum of three years of experience in their respective field and having a child with age group between 3-9 were selected for the study. Entrepreneurs who had partnership and was divorced/single were excluded from the study. At the beginning of the session each participant was briefed about the study. Informed consent was taken from the participants.

A set of open-ended questions were chosen to elicit the information required based on the objectives of the study. Data were collected through individual interviews. In-depth interviews were optimal for collecting data on individuals' perspectives, and experiences was explored. The participant provided the information through verbal interchange and conversation. Non-verbal behaviors and the interview context were also noted and it became the part of the data. Semistructured interview: It was developed by the researcher based on review of literature and discussion with the guide. A thematic analysis was used for data analysis. Interview response was coded and similar codes were grouped into themes and subthemes for further analysis.

\section{RESULTS AND DISCUSSION}

TABLE I(A) FACTORS THAT INFLUENCE COMMITMENT TO ENTREPRENEURIAL VENTURE.

\begin{tabular}{|c|c|c|}
\hline THEMES & $\begin{array}{l}\text { SUB- } \\
\text { THEMES }\end{array}$ & STATEMENTS \\
\hline $\begin{array}{l}\text { Individual } \\
\text { Factors That } \\
\text { Influence } \\
\text { Commitment }\end{array}$ & $\begin{array}{l}\text { Distraction } \\
\text { from physical } \\
\text { pain }\end{array}$ & $\begin{array}{l}\text { "I wanted to come out of all the } \\
\text { physical issues and concentrate } \\
\text { on my work which was my } \\
\text { diversion from experiencing pain } \\
\text { after my delivery" } \\
\text { "I may have a conflict at home } \\
\text { and keep thinking about it. But } \\
\text { once I come to my office my } \\
\text { mind gets totally diverted and } \\
\text { starts concentrating on work } \\
\text { which eventually releases my } \\
\text { stress" } \\
\text { "I feel stronger and content with } \\
\text { myself. I think it's because I run } \\
\text { my own firm and wouldn't have } \\
\text { got this feel if I was working } \\
\text { under someone" } \\
\text { "People had told me to quit my } \\
\text { firm when I delivered my second } \\
\text { baby since I had lots of physical } \\
\text { issues, but I never gave up. I took } \\
\text { a break for } 6 \text { months and back on } \\
\text { work" }\end{array}$ \\
\hline
\end{tabular}

Though there are many challenges faced by the mothers who are entrepreneurs, they never give up .They still don't sacrifice their work at any cost. Certain factors make them continue with their entrepreneurial venture. Most of the factors which influence the individual for the commitment to work are intrinsic and they are discussed below.

\section{Distraction from physical pain:}

The most common physical and emotional changes during pregnancy are very difficult to hide from the outside world. As the fetus grows, so does the abdomen of the mother. During the 40 weeks of pregnancy, the expectant mom will go through a huge list of physical and emotional changes. The participants of my study used their official work as a distraction from their physical pain. They feel that concentrating on their work makes them forget the physical pain they undergo.

\section{Distraction from family issues:}

My participants underwent many conflicts from within and with the family members but they tried to use their work life as a defense mechanism. They feel that every time they enter their work place they completely stay focused on their work which helps them to get distracted from the issues they face at home.

\section{Autonomy:}

Most of the mothers feel to be more independent and happy about self whenever they enter their workplace. They feel stronger and content with self.

Stronger determination: 
Though they face lot of difficulties, one factor was very common among the participants. As entrepreneurs they feel strongly determined to continue their entrepreneurial venture.

TABLE II(B) SHOWS THE STRATEGIES USED TO BALANCE THE ROLES.

\begin{tabular}{|c|c|c|}
\hline THEMES & SUB-THEMES & STATEMENTS \\
\hline $\begin{array}{l}\text { Effective } \\
\text { Planning }\end{array}$ & $\begin{array}{l}\text { Time } \\
\text { Management } \\
\text { Pre-Planning } \\
\text { Selfcare }\end{array}$ & $\begin{array}{l}\text { "I don't work after } 3 \text {. I } \\
\text { spend my time only with } \\
\text { children after } 3 \text { pm." } \\
\text { "I write down what has to } \\
\text { be done tomorrow the } \\
\text { previous night. Also, I } \\
\text { take and keep the clothes } \\
\text { to be worn the next day } \\
\text { for myself and my child } \\
\text { the previous night itself" } \\
\text { "I do yoga for one hour } \\
\text { every morning which } \\
\text { makes me to stay } \\
\text { energized for the whole } \\
\text { day" } \\
\text { "I go in for an oil } \\
\text { massage once a week and } \\
\text { relax myself" }\end{array}$ \\
\hline & $\begin{array}{l}\text { Assistance from } \\
\text { Others }\end{array}$ & $\begin{array}{l}\text { "I have a maid to cook at } \\
\text { home, so that I get time to } \\
\text { spend with my children." }\end{array}$ \\
\hline
\end{tabular}

\section{Effective planning:}

Some of the strategies they use to balance the roles are discussed below.

\section{Time management:}

Mothers have the best time management skills as they perform multiple roles in their lifetime. In order to balance both the roles as a mother and an entrepreneur, they schedule their time in a right manner and they strictly follow that as they feel each minute is very important in their life. They maintain a regular sleeping pattern. Most of my participants do work after $3 \mathrm{pm}$. This is because they want to spend their evening with children only. They feel easy to manage time between work and home as there is a time flexibility as entrepreneurs unlike working under someone.

\section{Preplanning:}

The response from my participants showed that the mothers work in a very systematic manner in order to balance their roles. The effort of preplanning is required for them to be directional in their work. Most of them make plans the prior day of what to do the next day. They make organizers, set reminders of their work be it at home or at workplace.

\section{Selfcare:}

Working mothers are the ones who needs more motivation and energy for them to maintain a balance between the works. Some of my participants spend time in physical workouts like going to gym and doing yoga in the early mornings. They also feel indulging in such activities keeps them motivated the entire day.

Every women wants to look good. According to a research done by Siemen in 1998, women after marriage doesn't spend more money on cosmetics than women who are unmarried. But that's not the case with entrepreneurs. They believe that being an entrepreneur it is a social need that they have to present themselves better in front of people. Most of them wants to groom themselves in a attractive way. They do go to beauty parlors occasionally to take care of them.

From indulging in the above such activities, they distract themselves from the routine and maintain their wellbeing which helps them to balance between both the roles.

\section{Assistance from others:}

All of the participants had a maid at home to help them. They feel that having a maid at home definitely helps them to concentrate on their work better and it reduces a lot of stress.

TABLE I(C) THE ISSUES FACED BY THE MOTHERS.

\begin{tabular}{|c|c|c|}
\hline THEMES & $\begin{array}{l}\text { SUB- } \\
\text { THEMES }\end{array}$ & STATEMENTS \\
\hline \multirow[t]{5}{*}{ Issues Faced } & $\begin{array}{l}\text { Emotional } \\
\text { Conflicts }\end{array}$ & $\begin{array}{l}\text { "Sometimes though I spend } \\
\text { enough time with my child, I } \\
\text { feel guilty at the prospect of } \\
\text { losing quality time with my } \\
\text { child." }\end{array}$ \\
\hline & Role Burden & $\begin{array}{l}\text { "My in-laws doesn't help me in } \\
\text { household chores" }\end{array}$ \\
\hline & & $\begin{array}{l}\text { "Always I'm the one who } \\
\text { attends parent meeting in my } \\
\text { child's school" }\end{array}$ \\
\hline & $\begin{array}{l}\text { Lack of } \\
\text { Intimacy }\end{array}$ & $\begin{array}{l}\text { "Without even a break of } 10 \\
\text { minutes for myself I come to } \\
\text { my bed at } 11 \text { everyday with } \\
\text { fully exhausted body and mind. } \\
\text { And I feel intimacy is reduced } \\
\text { because of this" }\end{array}$ \\
\hline & $\begin{array}{l}\text { Inconsistent } \\
\text { Parenting }\end{array}$ & $\begin{array}{l}\text { "I want my child to rise and } \\
\text { sleep early, but my husband is } \\
\text { very lethargic he allows my } \\
\text { child to sleep, to procrastinate } \\
\text { things etc., which brings a } \\
\text { conflict with my husband" }\end{array}$ \\
\hline
\end{tabular}




\section{Emotional conflicts:}

The mothers feel that they aren't spending enough quality time with their children. The children sometimes feel not being loved by the parents. There starts an emotional conflict

\section{Role burden:}

Women feel that the amount of work they have to undertake in their homes is quite taxing as they have to attend to multifarious types of works. If they have to seek job besides their domestic commitment, it would mean a tremendous burden of work on them. Indian female workers still operate under certain limitations and hardships. One of the most common problems faced by a woman is the dual role she has to play on the domestic front and work place. Particularly, the married woman working with small children find this dual responsibility a cause of great mental and physical strain. For them the working hours are long-eight hours at the place of employment and at least four hours at home. Usually husband and sometimes even the in-laws do not extend any help in the household chores. If it is a joint family the mother in-law or the sisters- in-law feel that they work for the whole day in the house when she is in the office. Now it is her turn to work. If she is with her husband or children they feel that she is not sharing their work. They often criticize and abuse her. But in some households working itself is a cause of problems. The women feel the guilt of neglecting the duties of a housewife. They try to put in more and more efforts at home. She takes extra care to satisfy her and the family. This in turn may result in health problems, depression and decreased work output.

\section{Lack of intimacy:}

Some men may gradually withdraw from work in case their wives are working. They tend to leave all the responsibilities of running the house on them. In the beginning a woman does not mind, but gradually she realizes the burden. He graciously gives a little money on specific demands and argues that after all she is earning and that she could run the house on her own. Moreover, he takes pride that he is not dabbling in her dealings. Some women often complain that they are misunderstood. Due to exhaustion, they could not respond to the husband's sexual needs They may be alleged to have illegitimate relations with some colleagues or boss. They are inhumanely treated, tortured and even beaten. Women feel hurt by such humiliating actions of the husbands, especially when their integrity is questioned.

\section{Inconsistent parenting:}

Most of the mothers feel that the conflicts between the spouse and them is because of the difference in parental approach. The mothers want their child to be perfect and disciplined whereas the fathers feel that the children should not be pressured at this age. For instance, the mothers want their children to wake up early everyday but the fathers don't mind child sleeping for some more time. There the conflict arises.
TABLE I (D) FACTORS CONTRIBUTING ROLE SATISFACTION.

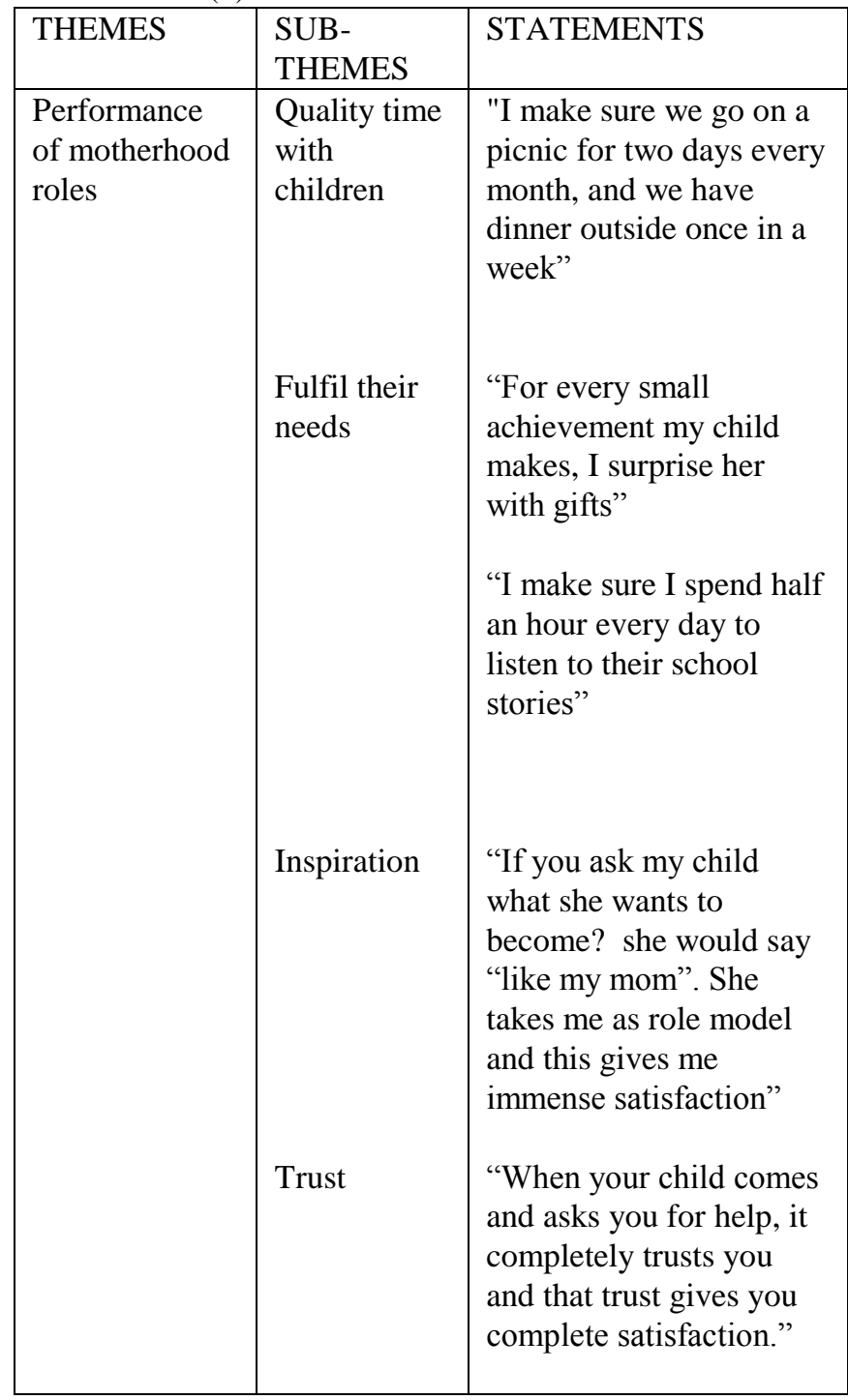

\section{Performance of motherhood role:}

As mothers they have complete satisfaction with their roles. There are few factors contributing to the role satisfaction.

\section{Quality time with children:}

Mothers feel that the time they get to spend with their children must make their children happy and satisfied. They fulfil their needs, they listen to their daily happenings in their school, take them to picnic every two weeks once etc.

\section{Inspiration:}

They feel that they are totally satisfied as mother when their child takes them as inspiration. This also gives them satisfaction with self.

\section{Trust:}

Childhood is a unique age span to establish trust. Trust emerges in response to care and creates the foundation for a child's identity that will later encompass three feelings firstly, a feeling that "everything is fine"; secondly, a feeling that the child is becoming his/her own true self; and thirdly, a feeling that he/she is becoming a person that others would like $\mathrm{him} /$ her to become. 
Mothers feel that this strong bond of trust of their child towards them gives them a complete satisfaction as mothers.

TABLE I(E) SHOWS THE SOCIAL SUPPORT.

\begin{tabular}{|c|c|c|}
\hline THEMES & $\begin{array}{l}\text { SUB- } \\
\text { THEMES }\end{array}$ & STATEMENTS \\
\hline $\begin{array}{l}\text { Social } \\
\text { Support }\end{array}$ & Neighborhood & $\begin{array}{l}\text { "My parents come } \\
\text { home to take care of } \\
\text { my children whenever } \\
\text { travel for work" } \\
\text { "Moral support and } \\
\text { advice I depend on my } \\
\text { parents. I feel for any } \\
\text { girl both before and } \\
\text { after marriage parents } \\
\text { are the pillars." } \\
\text { "When I'm not well or } \\
\text { had to go for work, } \\
\text { they don't mind all the } \\
\text { way down to take care } \\
\text { of me." } \\
\text { "I feel more } \\
\text { comfortable to } \\
\text { approach my parents } \\
\text { for any help than my } \\
\text { in-laws" } \\
\text { "My neighbors are so } \\
\text { nice to my children } \\
\text { and take care of them } \\
\text { very well whenever } \\
\text { I'm late from work" }\end{array}$ \\
\hline
\end{tabular}

\section{Social support:}

Family:

Most of the mothers felt they get their social support from their parents. Also, they feel that they are more comfortable in depending upon their parents than their in-laws. Also, they feel that their moral and financial support they rely on their parents that on the spouse or in-laws.

Neighborhood:

Most of my participant felt that they have really good neighborhood. They take care of their children in their absence. And they believe that their neighbors genuinely feel the responsibility of taking care of their children when they are out for work.

\section{CONCLUSION}

The study had found that the mothers were satisfied with their roles because of certain factors like quality time they spend with their children and the trust children have on them etc., It was also found that there were issues such as role burden, lack of intimacy with the spouse, inconsistent parenting and they experienced emotional conflicts from within. They used strategies such us effective time management techniques, pre planning and taking care of self in order to maintain a balance between both the roles.

\section{ACKNOWLEDGMENT}

Aarthi P A thanks Dr.Lakshmi J Assistant Professor, Jain University, for her constant guidance and support for this study. Special thanks to the entrepreneurs who participated in this study for their patience and support.

About Author (s):

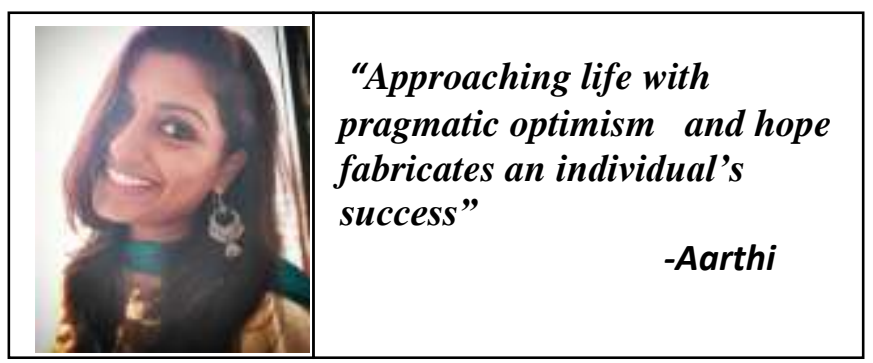

\begin{tabular}{|l|l|}
\hline \multirow{1}{*}{$\mid \begin{array}{l}\text { Dr. Lakshmi. J, assistant professor } \\
\text { and clinical psychologist in Jain } \\
\text { University, India. Her areas of } \\
\text { interest include psychotherapy, } \\
\text { cognitive behaviour therapy, } \\
\text { metacognitive therapy and } \\
\text { mindfulness. She has been a resource } \\
\text { person for workshops on cognitive } \\
\text { behaviour therapy. }\end{array}$} \\
\hline
\end{tabular}

\section{REFERENCES}

[1] Studymode.com (2013).Women Entrepreneurship in India-Problems and Perspectives. [online] Available at http://www.studymode.com/essays/WomenEntrepreneurship-In-India-Problem-And-Prospects1910499.html

[2] Entrepreneur.com (2017). Why mothers make better entrepreneur [online] Available at https://www.entrepreneur.com/article/303779

[3] Aegean Leung (2011), International Journal of Gender and Entrepreneurship, "Motherhood and entrepreneurship: gender role identity as a resource" 3 (3), pp.254-264.

[4] Aldrich, H. 1989. "Networking among Women Entrepreneurs". In Women owned Businesses Edited by: Hagan, G. and Sexton, D. 103-32.

[5] Ernst Kossek, E., \& Ozeki, C. (1998). Work-family conflict, policies, and the job-life satisfaction relationship: A review and directions for organizational behavior-human resources research. Journal of Applied 